\title{
Potencia Del Lenguaje EN TIEMPOS DE PANDEMIAS
}

María Elvira Rodríguez Luna ${ }^{1}$

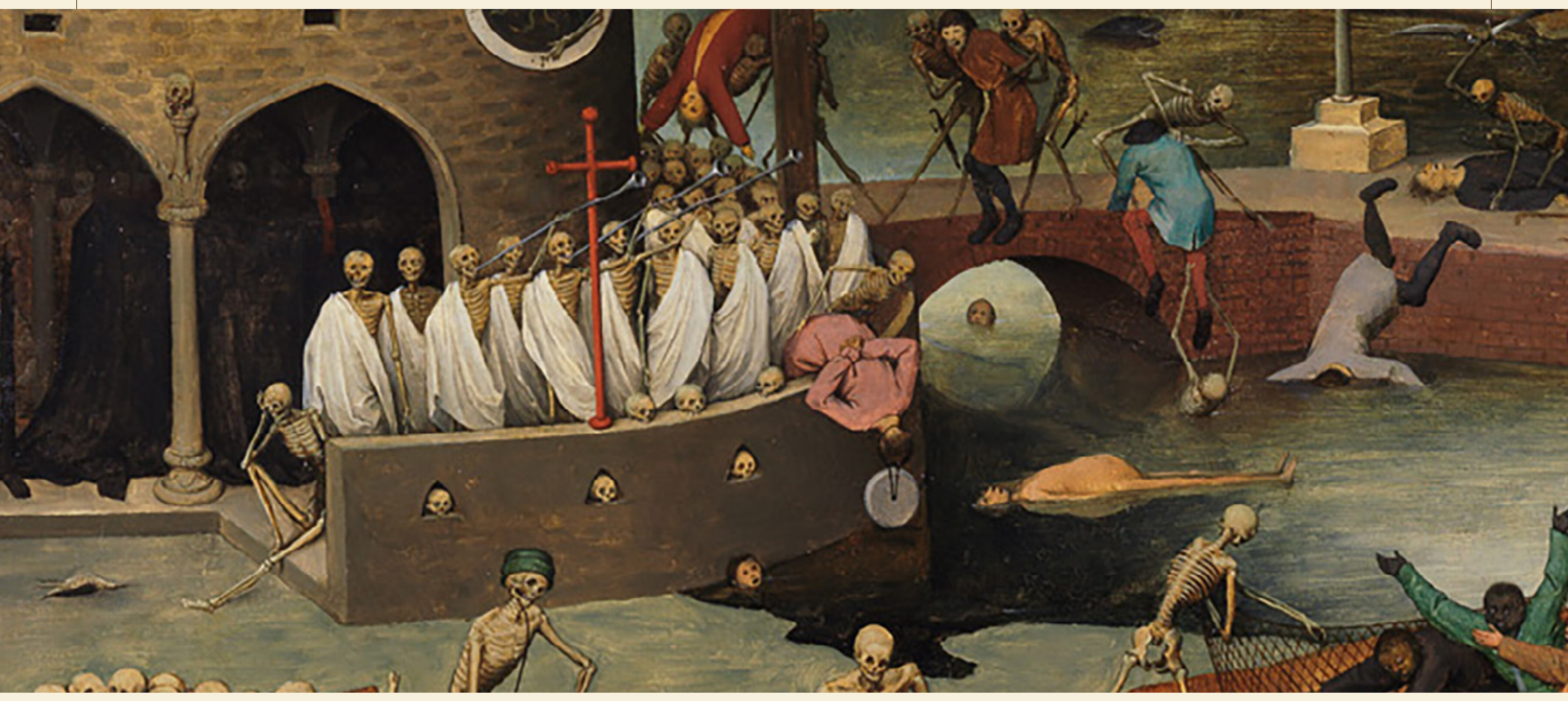

1 Doctora en Ciencias Pedagógicas. Profesora honoraria Universidad Distrital Francisco José de Caldas, Bogotá D. C. Correo electrónico: mariae.rodriguezluna@gmail.com ORCID https://orcid.org/0000-0002-9307-3545

Cómo citar: Rodríguez Luna, M. E. (2020). Potencia del lenguaje en tiempos de pandemias. Enunciación, 25(2, separata), XVII-XXI. https://doi.org/10.14483/22486798.17015 

ue la actual pandemia cambió el ritmo de nuestras vidas es un hecho innegable, como también lo es que, mientras nuestro espacio físico se estrechođon el confinamiento, nuestro tiempo se expandió y, con ello, pese al miedo y a la incertidumbre, surgieron momentos para nuevas formas de comunicación reflexión. La escuela también entró abruptamente en una nueva normalidad, que puede prolongarse, lo cual demanda acercamientos a lo que ha ocurrido, está ocurriendo y ocurrirá. A través del lenguaje, como capacidad que nos permite "representar no solo lo que es, sino lo que era, lo que será y lo que le gustaría que fuese" (Searle, 2010, p. 72), es viable proponer estrategias que incentiven en nuestros estudiantes su deseo de registrar, interpretar o recrear esta manera inédita de vivir. Las funciones y actividades del lenguaje tanto en la vida cotidiana, como en variadas obras literarias cuyos temas son las pestes, señalan su rol en la superación de situaciones pasmosas, bien sea para resistir ante lo desconocido, recrear una realidad que se vuelve insoportable o proyectar un después que siempre sobreviene.

El lenguaje, como institución social de la cual depende la existencia de las demás, reafirma su papel fundamental. En La peste, cuando el lenguaje abre y cierra el universo de la pandemia, los curiosos acontecimientos relatados por el cronista destacan esa función constitutiva y la progresiva aparición de indicios, configurándose un nuevo estado de cosas en la ciudad de Orán; periodo que culmina con la primera muerte que "marcó el fin de este periodo lleno de signos desconcertantes y el comienzo de otro, relativamente más difícil, en el que la sorpresa de los primeros tiempos se transformó poco a poco en pánico" (Camus, 1984, p. 21). Esa nueva realidad no apareció de plano: su representación se construyó gradualmente a partir de un juego de señales que llevaron a concluir la llegada de la peste.

Decretarse oficialmente la epidemia es crear una realidad que modifica las relaciones sociales. Por eso, la enunciación de la prefectura: "Declaren el estado de peste. Cierren la ciudad" (Camus, 1984, p. 50) hace que la realidad social gire en torno a ese único asunto. Entonces, "un sentimiento tan individual como es el de la separación de un ser querido se convirtió de pronto, desde las primeras semanas, mezclado a aquel miedo, en el sufrimiento principal de todo un pueblo durante aquel largo exilio" (Camus, 1984, p. 51). Las medidas adoptadas despojaron a los habitantes hasta de la pequeña satisfacción de escribir ya que "una nueva disposición prohibió toda correspondencia para evitar que las cartas fueran vehículo de infección" (Camus, 1984, p. 52). Tan solo les permitieron los telegramas que, por su reducido número de palabras y formas preestablecidas, terminaban por vaciarlos de sentido.

Hoy, los avances tecnológicos permiten la comunicación con amigos, familiares, seres amados: videollamadas, chats, correos electrónicos, tuits y otros medios han sustituido las cartas y los telegramas. La exploración de estas formas de escritura en las aulas abre espacios potentes para fortalecer la producción textual. El género epistolar, tan necesario como poco trabajado actualmente, cobra nuevo valor: desde enviarse mensajes formales, hacer reflexiones para uno mismo, escribir notas explicativas para resolver conflictos, comunicarse con estudiantes de otras ciudades y países, escribir cartas de amor, tarjetas o notas amables para los amigos secretos o diarios de confidencias, pueden ayudar a los estudiantes a sobrellevar la soledad, permitiéndoles avanzar en el dominio escritural. Además, son textos importantes para desarrollar la función expresiva del lenguaje, así se piense con Florentino Ariza en El amor en los tiempos del cólera, que "las cartas de amor han pasado de moda” (García Márquez, 2005, p. 96).

Ante situaciones de aislamiento y soledad, reflejadas en las calles vacías y los cercos impuestos a las actividades de comercio y esparcimiento, el lenguaje permite resistir. Cuando la ciudad de Florencia entra en la cuarentena 
provocada por la peste bubónica de 1348 con sus mortíferas consecuencias, un grupo de jóvenes decide refugiarse en la literatura:

[...] entiendo contar cien novelas, o fábulas, o parábolas o historias, como las queramos llamar, narradas en diez días, como manifiestamente aparecerá, por una honrada compañía de siete mujeres y de tres jóvenes, en los pestilentes tiempos de la pasada mortandad, y algunas canciones cantadas a su gusto por las dichas señoras. (Boccaccio, 1983, p. 6)

Su resistencia ante la muerte los convoca alrededor de la palabra para abstraerse del contagio y el dolor, de manera semejante a como lo hace Gustavo Aschenbach, en Venecia, al extasiarse en la belleza, pese a que "la peste, negada y escondida, seguía haciendo estragos en las callejuelas angostas" (Mann, 1983, p. 123).

Cuando promovemos actividades significativas que llevan a los estudiantes a hacer cosas con el lenguaje contribuimos a que le den forma a ese enemigo invisible llamado covid-19 al teatralizarlo, oralizarlo, representarlo y despojarlo de su hálito de misterio, con el fin de desmitificarlo y acorralarlo, para luego destruirlo, bien sea en una tira cómica, una historia de terror, un dibujo, una escultura, una viñeta, una historieta, un cuento o cualquier otro tipo textual, pues "nosotros somos las palabras que cuentan lo que somos" (Galeano, 1996, p. 4). La reescritura de cuentos tradicionales en los que toman vida personajes de la actualidad nacional es también un buen medio para sacar el dolor y convertirlo en risa, como lo hizo recientemente el periodista Samper Ospina en su columna Cuentos infantiles de pandemia (2020). Y qué decir del teatro que, al igual que la peste, "es una formidable invocación a los poderes que llevan al espíritu, por medio del ejemplo, a la fuente misma de sus conflictos" (Artaud, 2011, p. 29).
Instalar a los estudiantes en realidades que atenúen la ansiedad posibilita su proyección en el tiempo. En tal sentido, la lectura, como ventana al mundo, les ayuda a salir del encierro y participar de otras experiencias que, si bien pueden ser ficcionales, constituyen espejos que revelan de qué manera el lenguaje y la lengua materna aminoran el peso del enclaustramiento, la incomunicación, la enfermedad, la separación, la inestabilidad, la soledad, el olvido, la muerte, y en cierto modo, los alivian, al enseñarles que las situaciones excepcionales son finitas. Tal como se narra en el Éxodo, las plagas que azotaron a Egipto también terminaron con un renacer.

Cuando la peste del insomnio llegó a Macondo, su consecuencia más crítica fue la pérdida del lenguaje. Cuando el enfermo se acostumbraba a su estado de vigilia

[...] empezaban a borrarse de su memoria los recuerdos de la infancia, luego el nombre y la noción de las cosas, y por último la identidad de las personas y aún la conciencia del propio ser, hasta hundirse en una especie de idiotez sin pasado. (García Márquez, 2007, p. 56)

Para combatir tan extraña enfermedad recurrieron a sencillos juegos del lenguaje que podían convertirse en agotadores métodos de oralidad sin sentido ya que

Se reunían a conversar sin tregua, a repetirse durante horas y horas los mismos chistes, a complicar hasta los límites de la exasperación el cuento del gallo capón, que era un juego infinito en que el narrador preguntaba si querían que les contara el cuento del gallo capón, y cuando contestaban que no, el narrador decía que no les había pedido que dijeran que no, sino que si querían que les contara el cuento del gallo capón, [...] y así sucesivamente, en un círculo vicioso que se prolongaba por noches enteras. (García Márquez, 2007, p. 59) 
También cuenta que, luego de cierto tiempo, la cuarentena se naturalizó y la vida retomó su ritmo, aunque persistía el enorme problema de la pérdida de la memoria. Allí, el lenguaje con su capacidad para señalar, designar y construir la referencia les permitía no olvidar qué función cumplían los objetos o cómo se usaban y capturar la realidad con las palabras, posibilitándoles la interacción, sin caer en el olvido. Por eso, cuando su padre le comunicó alarmado que había olvidado hasta los hechos más impresionantes de su niñez, Aureliano le explicó su método, consistente en escribir el nombre de las cosas en un papel, y José Arcadio Buendía lo puso en práctica, como después lo hicieron todos:

Con un hisopo entintado marcó cada cosa con su nombre: mesa, silla, reloj, puerta, pared, cama, cacerola [...]. El letrero que colgó en la cerviz de la vaca era una muestra ejemplar de la forma en que los habitantes de Macondo estaban dispuestos a luchar contra el olvido: Esta es la vaca, hay que ordeñarla todas las mañanas para que produzca leche y a la leche hay que hervirla para mezclarla con el café y hacer café con leche. (García Márquez, 2007, p. 60)

Sin embargo, eran conscientes de que se trataba de una realidad escurridiza, pues estaban expuestos a olvidar el valor de la lengua escrita. Por eso, ante la ausencia de palabras, otras formas de lenguaje ayudaron a sobrellevar la situación: los sonidos de las campanitas de los chivos para que los forasteros pudieran identificarse como no portadores de la peste del insomnio o el daguerrotipo que les permitió verse plasmados "en una edad eterna sobre una lámina de metal tornasol" (García Márquez, 2007, p. 63).

Hoy, a falta de daguerrotipos, buenos son los medios que permiten hacer blogs, podcasts, videos para bailar, hacer ejercicios físicos y espirituales, teatro, títeres, realizar entrevistas, hacer fotografía y tantas otras modalidades de trabajo verbal y no verbal, que se constituyen en pretextos para la comunicación en el aislamiento. En la escuela, estos medios potencian la producción de todo tipo de textos, como el uso del videojuego Minecraft para representar la obra literaria leída, o la realización de montajes teatrales, la representación de personajes históricos y hasta la visita a grandes museos del mundo, parques naturales, pinacotecas, palacios y muchas otras partes a las que se puede viajar siguiendo un link $k^{1}$.

Ante la peste del olvido, no faltaron los relatos de juglares como Francisco El Hombre, ese anciano trotamundos de casi 200 años que derrotó al Diablo en un duelo de improvisación de cantos, mientras pasaba relatando las noticias más destacadas, siempre acompañado de su acordeón y de su vieja voz destemplada. "De modo que, si alguien tenía un recado que mandar o un acontecimiento que divulgar, le pagaba dos centavos para que lo incluyera en su repertorio" (García Márquez, 2007, p. 64), constituyéndose estos cantos en actos comunicativos donde "podemos observar y diferenciar la copresencia de seres reales y seres discursivos puestos en ejecución por el compositor" (Escamilla et al., 2005, p. 16).

Para enfrentar las cuarentenas, espontáneamente, entretejemos acciones lingüísticas y no lingüísticas que configuran sentidos compartidos a través de diversas formas de la oralidad e intentan compensar la soledad y el aburrimiento de los niños: refranes, coplas, adivinanzas, fábulas y cuentos son, entre otros, juegos verbales que buscan sacarlos del tedio y el miedo, situándolos en la dimensión lúdica del lenguaje. Esto ha hecho famoso al cuentero mexicano Percibald García, ese moderno juglar que durante el confinamiento decidió leer historias a niñas y niños en Tlatelolco, "cuando escuchó a uno de ellos gritar por la ventana: ¡Estoy aburrido!" (Infobae, 2020).

En los citados casos, oralidad y escritura, imágenes y otros símbolos confluyen y se interrelacionan para posibilitar la supervivencia, superar la soledad y ganarle a la peste

1 Véase, a manera de ejemplo, Grupo Lar (2020). 
del olvido. Así mismo, nos corresponde facilitarles a niños, niñas y jóvenes las condiciones adecuadas para que, desde las distintas funciones del lenguaje, a través del rap, el vallenato, las coplas, la reportería, los diarios de pandemia, las crónicas, las noticias y su análisis crítico, provoquemos "la liberación de la palabra, el placer de crear y recrear el sentido del mundo, la posibilidad de realizar sus fantasías" (Rodríguez y Jaimes, 2000, p. 67). Puesto que, hasta en los sueños, el lenguaje permite proyectarse y ver la realidad en otra dimensión o, como lo refiere Artaud (2011), anticiparse a los desastres y alejar la muerte:

Una noche de fines de abril o principios de mayo de 1720 , alrededor de veinte días antes que el buque Grand Saint $A n$ toine arribara a Marsella, coincidiendo con la más maravillosa explosión de peste de que haya memoria en la ciudad, Saint-Rémys, virrey de Cerdeña, a quien sus reducidas responsabilidades monárquicas habían sensibilizado quizá al más pernicioso de los virus, tuvo un sueño particularmente penoso: se vio apestado, y vio los estragos de la peste en su estado minúsculo. (p. 15)

Si todo llega y todo pasa, siempre tendremos un futuro para proyectar, a tono con nuestro pasado, nuestras historias de vida, y las experiencias dejadas por este tiempo de pandemia; esa desagradable visitante que algún día se irá tan silenciosa e imperceptiblemente como llegó. Sin embargo, no hay que perder de vista que el covid-19, aunque jamás con la furia de las pestes que azotaron a Egipto, Marsella, Venecia, Florencia y tantas ciudades del Oriente, deja muchos efectos desmoralizadores que habrá que canalizar a través del lenguaje pues "todo lo que el hombre puede ganar al juego de la peste y de la vida es el conocimiento y el recuerdo" (Camus, 1984, p. 211).

\section{Referencias}

Artaud, A. (2011). El teatro y la peste. En El teatro y su doble (pp. 15-

32). Ediciones Incógnita.

Boccaccio, G. (1983). Cuentos del Decamerón. Bogotá: Oveja Negra.

Camus, A. (1984). La peste. Bogotá: Oveja Negra.

Escamilla, J. et al. (2005). La canción vallenata como acto discursivo. Barranquilla: Universidad del Atlántico.

Galeano, E. (1996). El libro de los abraz̧os. Bogotá: Tercer Mundo.

García Márquez, G. (2007). Cien años de soledad. Bogotá: Alfaguara.

García Márquez, G. (2005). El amor en los tiempos del cólera. Barranquilla: Ediciones La Cueva.

Grupo Lar (17 de abril de 2020). Guia Lifestyle Cuarentena de Grupo Lar. Recuperado de https://www.grupolar.com.mx/ guia-lyfestile-cuarentena/

Infobae (30 de julio de 2020). El moderno juglar que lee historias a niñasy niños durante el confinamiento en Tlatelolco. Recuperado de https:// www.infobae.com/america/mexico/2020/07/30/el-moderno-juglar-que-lee-historias-a-ninas-y-ninos-durante-el-confinamiento-en-tlatelolco/

Mann, T. (1983). La muerte en Venecia. Bogotá: Seix Barral, Oveja Negra.

Rodríguez, M. E. y Jaimes, G. (2000). Juegos del lenguaje en la educación inicial. Enunciación, 4(1), 76-81.

Samper Ospina, D. (6 de septiembre de 2020). Cuentos infantiles de pandemia. LosDanieles.com. Recuperado de https://losdanieles. com/daniel-samper/cuentos-infantiles-de-pandemia/

Searle, J. (2010). Los principios básicos de la ontología social. En Noguera, J. (Ed.) Teoría sociológica analitica (63-84). Madrid: Centro de Investigaciones Sociológicas.

\section{(c) (1) $(9)$}

